\title{
A Simple Superovulation Method of A Single Injection of Follicle-Stimulating Hormone Combined with Equine Chorionic Gonadotropin for Superovulation of Suffolk Ewes During the Breeding Season: I. Effects of Different Treatments on the Endocrine Profiles
}

\author{
Hiroko WATANABE, Akio MIYAMOTO, Midori OKADA, \\ Naohisa ISHIDA, Hidenori KIMURA and Yutaka FUKUI \\ Laboratory of Animal Genetics and Reproduction, Obihiro University of Agriculture \\ and Veterinary Medicine, Inada-cho, Obihiro-shi, Hokkaido 080-8555, Japan
}

\begin{abstract}
Two trials were conducted to investigate a simple superovulation method for Suffolk ewes during the breeding season. The method involves a single injection of porcine follicle-stimulating hormone $(\mathrm{pFSH})$ combined with equine chorionic gonadotropin $(\mathrm{eCG})$ and was evaluated by measuring the concentrations of plasma hormones (estradiol-17 $\beta\left(\mathrm{E}_{2}\right)$, progesterone $\left(\mathrm{P}_{4}\right)$, luteinizing hormone ( $\mathrm{LH})$ and follicle-stimulating hormone (FSH)). The ewes were treated with a vaginal sponge containing synthetic steroid with progestative action (P sponge) for 12 days in both trials. In Trial 1 (conducted in 1995), 18 ewes received a single injection (F1) or multiple injections (F6) of a total of $20 \mathrm{mg} \mathrm{pFSH}$, and in combination with an injection of $500 \mathrm{IU}$ eCG $(\mathrm{F} 1+\mathrm{P}, \mathrm{F} 6+\mathrm{P})$. The injections were conducted on Day - 2 (Day 0 was the day of $P$ sponge removal). In trial 2 (conducted in 1996), 24 ewes were given single injections of pFSH and eCG at different times; (i) both hormones on Day - 2 (F-2/P-2), (ii) pFSH on Day -2 and eCG on Day - 1 (F-2/ P-1), and (iii) both hormones on Day - 1 (F-1/P-1). One hundred micrograms of an analogue of gonadotropin-releasing hormone $(\mathrm{GnRH})$ was administered on Day 1 in Trial 1 and at the detection of estrus in Trial 2. Frozen-thawed semen was inseminated in utero using a laparoscope at $30 \mathrm{~h}$ and $38 \mathrm{~h}$ after P sponge removal in Trial 1 and at 18 hours after the detection of estrus in Trial 2. Blood samples were collected from the jugular vein. $\mathrm{E}_{2}, \mathrm{P}_{4}, \mathrm{LH}$ and FSH were assayed by second-antibody enzyme immunoassays. $\mathrm{F} 1+\mathrm{P}$ showed similar endocrine profiles to those of $\mathrm{F} 6$ and $\mathrm{F} 6+\mathrm{P}$ with a preovulatory $E_{2}$ peak after $P$ sponge removal, but $F 1$ did not show a clear preovulatory $E_{2}$ peak. The $E_{2}$ concentration in F-2/P-1 rose biphasically; there was a rise just after injection of $\mathrm{pFSH}$ and then another rise after P sponge removal. Simultaneous injections of $20 \mathrm{mg}$ pFSH and $500 \mathrm{IU}$ eCG may reduce the $\mathrm{E}_{2}$ elevation. We concluded that a good ovarian response comparable to the multiple injection method can be achieved by the present simple superovulation method.

Key words: pFSH, eCG, Superovulation, Ewes, Endocrine profiles.
\end{abstract}

(J. Reprod. Dev. 44: 169-176, 1998)

$\mathbf{F}$ SH or eCG are gonadotropins widely utilized for induction of superovulation in ewes. Because of the short half-life (30-110 min) of FSH, it

Accepted for publication: December 26, 1997

Correspondence: Y. Fukui is necessary to inject it repeatedly [1], and the administration of decreasing doses gave more successful results than that administrating of a constant dose [2]. Multiple injections of FSH in decreasing doses resulted in increasing the number of corpora lutea, the number of recovered 
oocytes and the pregnancy rate following transfer in cows [3]. In ewes, a single high dosage of eCG $(1,000-1,200 \mathrm{IU})$ could induce a more successful superovulation than multiple injections of FSH [4]. However, the administration of a high dosage of eCG is not recommended owing to its long halflife period, which varies from 50-120 h [1]. Its relatively high LH-like activity may cause abnormal premature activation of sheep oocytes, and the follicular environment would become unsuitable for maturation. Therefore the oocytes would prematurely age before ovulation [5], resulting in decreasing the yield of fertilized eggs [6]. Furthermore, a high dose of eCG induces many anovulatory follicles [7]. Multiple injections of a high dose of FSH combined with a low dose of eCG is now conventionally used in ewes to induce superovulation $[2,4,8]$, as it can induce a higher ovulatory response than the multiple injections of FSH alone [9]. However, the use of multiple injections, such as 6 times during 2 or 3 days, increases the workload as well as causes stress in animals.

Evans et al. [10] showed that a single injection of a high dose $(15 \mathrm{mg})$ of FSH in combination with a low dose (300 IU) of eCG resulted in a satisfactory superovulation and embryo recovery as compared with multiple injections of FSH combined with a low dose of eCG in ewes, and equally successful results were obtained in goats [11]. Yamada et al. have also reported similar results in ewes during the breeding season [12] and anestrous season [13]. However, the endocrinological basis of this simple superovulation method is not well understood. In order to obtain a better understanding of the endocrine profiles around ovulatory periods caused by a simple superovulation method, we compared the endocrine profiles of a single injection of 20 $\mathrm{mg} \mathrm{pFSH}$ and multiple injections of the same dose of $\mathrm{pFSH}$, and in combination with the administration of 500 IU eCG in Trial 1. In Trial 2, we further observed the endocrine profiles after single injections of $20 \mathrm{mg}$ pFSH and $500 \mathrm{IU}$ eCG at three different times.

\section{Materials and Methods}

\section{Animals}

Trial 1 was conducted in 1995 (September to November) with 18 parous 2- to 6-year old Suffolk ewes and Trial 2 was conducted in 1996 (October to December) with 24 non-parous 2- to 3-year old Suffolk ewes. The ewes were fed hay and concentrates with water provided ad libitum.

\section{Treatments}

To synchronize estrus of ewes, which were at unknown stages of the estrous cycle, intravaginal sponges (P sponge) were inserted for 12 days before experiments. In Trial 1 , the sponges which were impregnated with $60 \mathrm{mg}$ 6-methyl-17-acetoxyprogesterone (MAP: The upjohn International Ltd, Australia) were used and in Trial 2, the sponges which were impregnated with $40 \mathrm{mg}$ Flugestone acetate (FGA, Chrono-gest: Intervet International B.V., Holland) were used.

In Trial 1, ewes were divided into 4 groups to investigate the effects of a single intramuscular injection of $20 \mathrm{mg}$ pFSH (Antorin: Denka Chemical Co., Japan) and the combination with an intramuscular injection of eCG (Serotropin: Teikokuzoki Co., Japan). The first group (F1: $\mathrm{N}=4$ ) received a single injection of $20 \mathrm{mg} \mathrm{pFSH}$ on Day -2 (Day $0=$ the day of $\mathrm{P}$ sponge removal). The second group received multiple injections ( $\mathrm{F} 6: \mathrm{N}=4$ ) of the same total dose of pFSH in decreasing doses $(5,5,3,3,2$, $2 \mathrm{mg}$ ) over Day -2 to Day 0 . The third and fourth groups received an additional injection of $500 \mathrm{IU}$ eCG on Day $-2(\mathrm{~F} 1+\mathrm{P}: \mathrm{N}=6$ and $\mathrm{F} 6+\mathrm{P}: \mathrm{N}=4)$ to the treatments for the first and second groups, respectively.

Trial 2 was designed to study the optimum timing for the injections of $20 \mathrm{mg}$ pFSH and $500 \mathrm{IU}$ eCG for a simple superovulations method. Ewes divided into 3 groups: one was treated with simultaneous injections of single injections of $\mathrm{pFSH}$ and eCG on Day - 2 (F-2/P-2: N=9), the second was treated with a single injection of $\mathrm{pFSH}$ on Day -2 followed by a single injection of eCG on Day - 1 (F-2/P-1: N=7), and the third was treated with simultaneous injections of both hormones on Day - 1 (F-1/P-1: N=8).

The ewes in Trial 1 were examined for estrus every $2 \mathrm{~h}$ from $-12 \mathrm{~h}$ to $36 \mathrm{~h}(0 \mathrm{~h}$ : the time of $\mathrm{P}$ sponge removal) using an entire ram aproned and equipped with marking harness and crayon. On Day 1, all ewes were injected intramuscularly with $100 \mu \mathrm{g}$ analogue of gonadotropin releasing hormone (GnRH, Conceral: Takeda lndustrial Co., Japan). Thirty $\mathrm{h}$ and $38 \mathrm{~h}$ after $\mathrm{P}$ sponge removal, frozen-thawed semen containing $4.8 \times 10^{8}$ spermatozoa per ewe, were deposited into in the uterine 
horns with an aid of a laparoscope according to the method of Maxwell et al. [14 ]. In Trial 2, the ewes were observed for estrus every $6 \mathrm{~h}$ from $6 \mathrm{~h}$ to $30 \mathrm{~h}$, injected with $100 \mu \mathrm{g} \mathrm{GnRH}$ at the time of estrus detection, and inseminated artificially with a laparoscope $18 \mathrm{~h}$ after estrus detection with frozen-thawed semen containing $5.3 \times 10^{8}$ spermatozoa per ewe. For each trial, the semen was collected from 6 Suffolk rams by artificial vagina. The semen used in Trial 1 was collected in 1991 to 1994 and the semen used in Trial 2 was collected 1996. The good-quality semen were diluted 1:2 with diluent consisting of $300 \mathrm{mM}$ Tris (hydroxymethyl aminomethane), $127.75 \mathrm{mM}$ glucose, $94.75 \mathrm{mM}$ citric acid, 15\% v/v egg yolk and $5 \% \mathrm{v} / \mathrm{v}$ glycerol and were frozen, and thawed according to the method of Salamon and Visser [15] as modified by Fukui [16]. The oocyte recovery was conducted on Day 7 or Day 8 in Trial 1 and on Day 8 in Trial 2.

\section{Blood sampling and $P_{4}, E_{2}$ and $L H$ assays}

Blood samples were collected from all ewes in Trial 1 in EDTA-2Na evacuated tubes by jugular venipuncture. In trial 2, blood was collected from 4 ewes in each of the group. For the results, we used the data from the ewes having normal corpora lutea (Trial 1; $\mathrm{F} 1 \mathrm{~N}=3, \mathrm{~F} 1+\mathrm{P} \mathrm{N}=3, \mathrm{~F} 6 \mathrm{~N}=3, \mathrm{~F} 6+\mathrm{P}$ $\mathrm{N}=4$. Trial 2; F-2 / P-2 N=2, F-2/P-1 N=4, F-1/P-1 $\mathrm{N}=3$ ). Plasma was separated by centrifugation $(1630 \times \mathrm{g}, 15 \mathrm{~min})$ at $4 \mathrm{C}$ and stored at $-30 \mathrm{C}$ until assayed. The blood samples for measuring $\mathrm{E}_{2}, \mathrm{P}_{4}$ and FSH were collected twice a day from Day -5 to Day -3 , every 6 h from Day - 2 to Day 1, and once a day from day 2 to the day of embryo recovery. The blood samples for the LH assay were collected every $2 \mathrm{~h}$ from $-18 \mathrm{~h}$ to $36 \mathrm{~h}$ in Trial 1 and from $6 \mathrm{~h}$ to $38 \mathrm{~h}$ in Trial 2. Plasma $\mathrm{E}_{2}$ [17] and $\mathrm{P}_{4}$ [18] were extracted by diethylether and measured by the second-antibody enzyme immunoassays (EIA). LH [19] was measured by EIA using the biotin-streptavidin amplification technique. Intra- and inter-assay coefficients of variation were within $13 \%$. The cross-reactivities of $\mathrm{LH}$ were $0.5 \%$ for $\mathrm{pFSH}$ and $4.3 \%$ for eCG, respectively.

\section{FSH assay}

Plasma concentrations of FSH were measured by a modified method for assay of LH by Mutayoba et al. [19]. The minimum and maximum detection limit were $0.4 \mathrm{ng} / \mathrm{ml}$ and $25.0 \mathrm{ng} / \mathrm{ml}$, respectively. The intra-assay and inter-assay coefficients of variation for $\mathrm{N}=106$ samples were $13.8 \%$ and $16.7 \%$. The correlation between values in EIA and RIA of the 106 samples was 0.86 . The crossreactivities of anti-oFSH were $0.9 \%$ for $\mathrm{pFSH}$ and $2.0 \%$ for eCG, respectively.

\section{Statistical analysis}

Data in the endocrine profiles were tested on uniformity of variance and analyzed by Duncan's multiple range test to examine the differences in the values between the groups in Trial 1 and Trial 2 , and by a two sample t-test to compare the difference between the F1+P group in Trial 1 and the F-2/ P-2 group in Trial 2.

\section{Results}

The effects of a single injection and multiple injections of $20 \mathrm{mg} p F S H$, and in combination with an injection of 500 IU eCG (Trial 1)

The effects of a single injection and multiple injections of $20 \mathrm{mg} \mathrm{pFSH}$, and in combination with an injection of 500 IU eCG on $E_{2}$ levels are shown for a representative ewe in Fig. 1.

A high dose of pFSH injection induced an instant $E_{2}$ elevation just after the injection in three ewes of F1 group (Fig. 1, top panel). This was only the peak observed and was considered to be the main $E_{2}$ peak of the F1 group (Table 1).

In the $\mathrm{F} 1$ group, the preovulatory $\mathrm{E}_{2}$ peak was not observed after $P$ sponge removal. On the other hand, the F1+P, F6 and F6+P groups showed a highly elevated preovulatory $\mathrm{E}_{2}$ peak that would cause a LH surge after $P$ sponge removal (Fig. 1 and Table 1). Biphasic $E_{2}$ secretion was observed in all the $\mathrm{F} 6+\mathrm{P}$ ewes: the first $\mathrm{E}_{2}$ peak was found just after $P$ sponge removal, and was as high as the second $E_{2}$ peak, which was the main preovulatory peak. The main $\mathrm{E}_{2}$ peak in $\mathrm{F} 1+\mathrm{P}$ was higher $(\mathrm{P}<0.05)$ and that of $\mathrm{F} 6+\mathrm{P}$ tended to be higher $(\mathrm{P}=0.075)$ than in the $\mathrm{F} 1$ and $\mathrm{F} 6$ groups (Table 1). After the preovulatory peak, the $\mathrm{E}_{2}$ concentrations decreased quickly to basal levels in all groups.

The $\mathrm{P}_{4}$ level was less than $1 \mathrm{ng} / \mathrm{ml}$ during the period from $\mathrm{P}$ sponge removal to $36 \mathrm{~h}$ in all groups and began to rise over $2 \mathrm{ng} / \mathrm{ml}$ from Day 2 to Day 7 (data not shown). GnRH were administered at $24 \mathrm{~h}$, when the main $\mathrm{E}_{2}$ peak was observed in Trial 


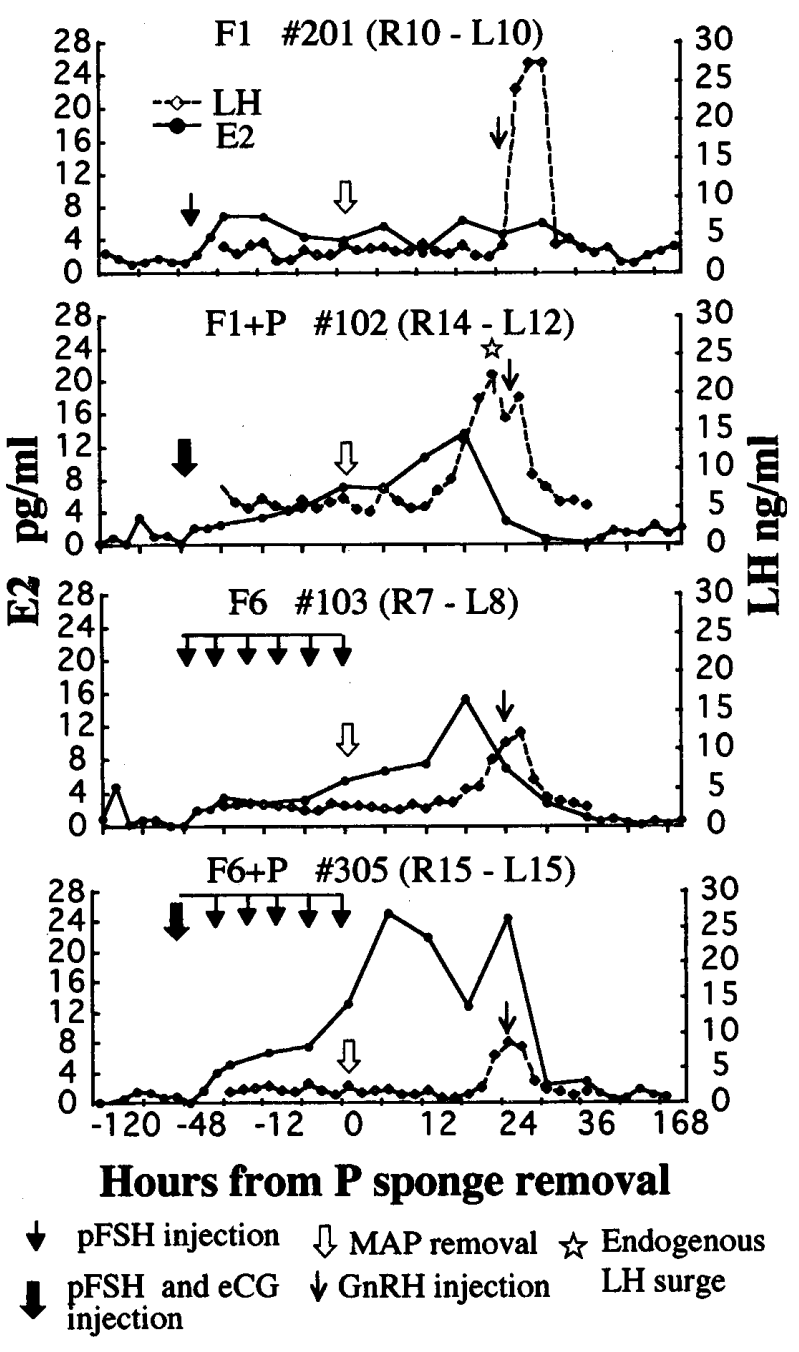

Fig. 1. Representative changes of $E_{2}$ and LH concentrations in plasma after a single injection (F1 and $\mathrm{F} 1+\mathrm{P})$ or a multiple injections ( $\mathrm{F} 6$ and $\mathrm{F} 6+\mathrm{P}$ ) of $20 \mathrm{mg}$ pFSH, and in combination with $500 \mathrm{IU}$ eCG $(\mathrm{F} 1+\mathrm{P}, \mathrm{F} 6+\mathrm{P})$ (Trial 1). \#: The number of individual ewes; $\mathrm{R}$ and L: number of ovulations from the right and the left ovaries, respectively.
1 , except for the F1 group. No preovulatory $E_{2}$ peak was observed in the F1 group. LH surges induced by $\mathrm{GnRH}$ injection were found around 26 h (Fig. 1).

The effects of single and multiple injections of pFSH on FSH levels are shown in Fig. 2. In this Figure, FSH data from the $\mathrm{F} 1$ and $\mathrm{F} 1+\mathrm{P}$ groups are pooled (upper panel) and the data from the F6 and $\mathrm{F} 6+\mathrm{P}$ groups are pooled (lower panel), since the changes in FSH concentration of the $\mathrm{F} 1$ and $\mathrm{F} 1+\mathrm{P}$, and of the $\mathrm{F} 6$ and $\mathrm{F} 6+\mathrm{P}$ were similar, respectively. After a single injection of $20 \mathrm{mg}$ pFSH, plasma concentrations of FSH peaked quickly, then decreased moderately with a slight oscillation. The FSH surge was induced by the GnRH injection concomitantly with the LH surge (Fig. 2). The FSH levels were maintained high by the multiple administration of $\mathrm{pFSH}$ for a longer period than by the single injection of pFSH (Fig. 2).

The effects of timing to inject $20 \mathrm{mg}$ pFSH and 500 IU eCG (Trial 2)

The effects of timing to inject $20 \mathrm{mg} \mathrm{pFSH}$ and eCG on $E_{2}$ from the beginning of the treatment to $\mathrm{P}$ sponge removal are shown in Fig. 3 . In this figure, the $E_{2}$ concentrations were averaged in each group. In contrast to the $\mathrm{F}-2 / \mathrm{P}-1$ group, both the F-2/P-2 and F-1/P-1 groups which received simultaneous injections of $\mathrm{pFSH}$ and eCG did not show an $E_{2}$ rise just after the injections (Fig. 3). The $E_{2}$ levels at $\mathrm{P}$ sponge removal were higher in the groups receiving the $\mathrm{pFSH}$ injection on Day -2 (F-2/P-2 and F-2/P-1) than that received the injection on Day $-1(\mathrm{~F}-1 / \mathrm{P}-1)(\mathrm{P}<0.05$, Table 2$)$.

The effects of the timing to inject $20 \mathrm{mg}$ pFSH and $500 \mathrm{IU}$ eCG on concentration of $\mathrm{E}_{2}$ in plasma of a representative ewe are shown in Fig. 4. The $\mathrm{E}_{2}$ profiles varied widely among the ewes. The $\mathrm{E}_{2}$ profile in the F-2/P-1 group was biphasic. The

Table 1. The effects of a single (F1) or multiple injections (F6) of $20 \mathrm{mg} \mathrm{pFSH}$, and in combination with $500 \mathrm{IU}$ eCG $(\mathrm{F} 1+\mathrm{P}, \mathrm{F} 6+\mathrm{P})$ on the $\mathrm{E}_{2}$ profiles

\begin{tabular}{|c|c|c|c|c|}
\hline Treatment & $\begin{array}{c}\mathrm{F} 1 \\
(\mathrm{~N}=3)\end{array}$ & $\begin{array}{l}\mathrm{F} 1+\mathrm{P} \\
(\mathrm{N}=3)\end{array}$ & $\begin{array}{c}\mathrm{F} 6 \\
(\mathrm{~N}=3)\end{array}$ & $\begin{array}{l}\mathrm{F} 6+\mathrm{P} \\
(\mathrm{N}=4)\end{array}$ \\
\hline Time of main $E_{2}$ peak $(h)$ & $-12.0 \pm 3.5^{\mathrm{a}}$ & $20.0 \pm 0.0^{\mathrm{b}}$ & $18.0 \pm 0.0^{\mathrm{b}}$ & $22.5 \pm 1.5^{\mathrm{b}}$ \\
\hline Conc. of main $\mathrm{E}_{2}$ peak $(\mathrm{pg} / \mathrm{ml})$ & $6.4 \pm 2.0^{c}$ & $28.7 \pm 7.6^{\mathrm{d}}$ & $7.3 \pm 4.0^{c}$ & $22.3 \pm 5.2^{\mathrm{cd}}$ \\
\hline
\end{tabular}

Data are expressed as mean \pm SEM. The times (h) are hours from P sponge removal. $a, b)$ Values with different superscripts are significantly different $(P<0.01)$. c, d) Values with different superscripts are significantly different $(\mathrm{P}<0.05)$. 


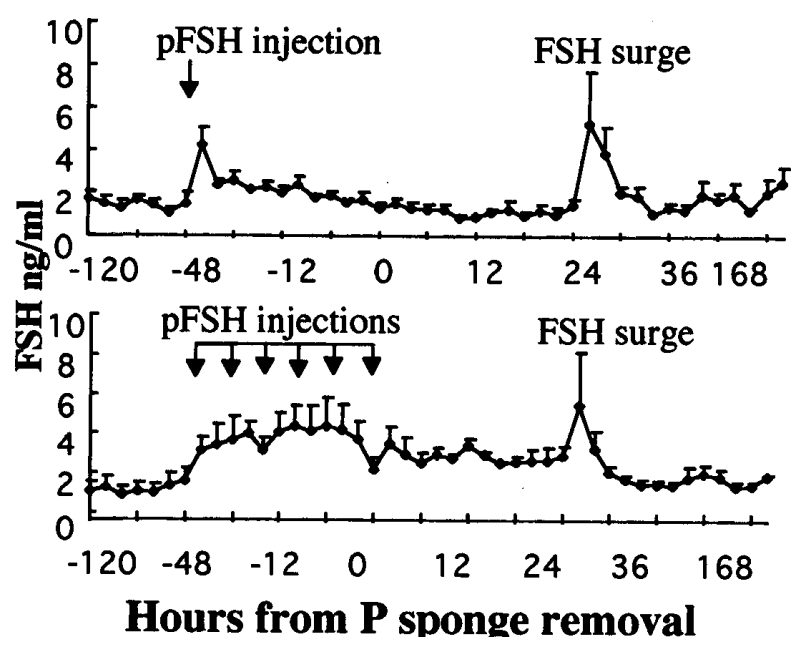

Fig. 2. The effects of a single injection (F1) or multiple injections (F6) of $20 \mathrm{mg} \mathrm{pFSH}$ on the FSH concentrations in plasma (mean \pm SEM). The upper panel shows pooled data of the $\mathrm{F} 1$ and $\mathrm{F} 1+\mathrm{P}$ groups and data in the lower panel shows pooled data of the $\mathrm{F} 6$ and $\mathrm{F} 6+\mathrm{P}$ groups.

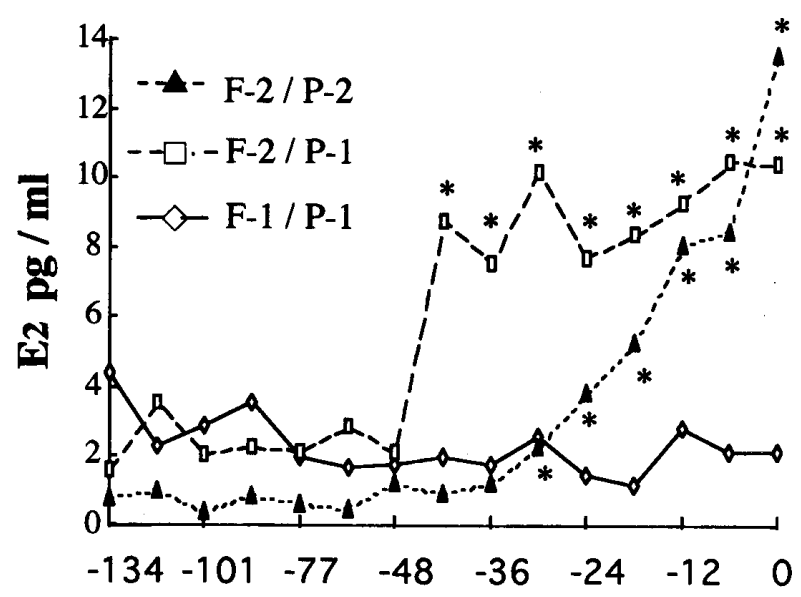

Hours from $P$ sponge removal

Fig. 3. The effects of timing to inject a single dose of pFSH and $\mathrm{eCG}$ on the endocrine profiles of $\mathrm{E}_{2}$ from the beginning of the treatment to $\mathrm{P}$ sponge removal. Ewes received a single injection of $20 \mathrm{mg}$ pFSH and 500 IU eCG. $(\boldsymbol{\Delta})$, both hormones on Day - 2 (F-2/ P-2 N=2); $\square)$, pFSH on Day -2 and eCG on Day $-1(\mathrm{~F}-2 / \mathrm{P}-1 \mathrm{~N}=4) ;(\diamond)$, both hormones on Day -1 $(\mathrm{F}-1 / \mathrm{P}-1 \mathrm{~N}=3) .{ }^{*}$, values differ significantly from the basal concentration of $\mathrm{E}_{2}(\mathrm{P}<0.05)$.

Table 2. The effects of timing of a single injection of $20 \mathrm{mg} \mathrm{pFSH}$ and $500 \mathrm{IU}$ eCG on $\mathrm{E}_{2}, \mathrm{~F}-2$ / P-2, both hormones given on Day - 2; F-2/P-1, pFSH given on Day -2 and eCG given on Day -1 ; F-1/P-1, both hormones on Day -1

\begin{tabular}{lccc}
\hline Treatment & $\begin{array}{c}\mathrm{F}-2 / \mathrm{P}-2 \\
(\mathrm{~N}=2)\end{array}$ & $\begin{array}{c}\mathrm{F}-2 / \mathrm{P}-1 \\
(\mathrm{~N}=4)\end{array}$ & $\begin{array}{c}\mathrm{F}-1 / \mathrm{P}-1 \\
(\mathrm{~N}=3)\end{array}$ \\
\hline $\mathrm{E}_{2}$ conc. at sponge removal $(\mathrm{pg} / \mathrm{ml})$ & $(8.3,18.8)^{\mathrm{c}}$ & $10.4 \pm 1.5^{\mathrm{d}}$ & $2.1 \pm 0.5^{\mathrm{d}}$ \\
Time of main $\mathrm{E}_{2}$ peak $(\mathrm{h})$ & $(18.0,0.0)$ & $4.5 \pm 7.9$ & $24.0 \pm 0.0$ \\
Conc. of main $\mathrm{E}_{2}$ peak $(\mathrm{pg} / \mathrm{ml})$ & $(13.5,18.8)$ & $26.2 \pm 10.0$ & $12.1 \pm 5.9$ \\
$\Delta \mathrm{E}_{2}$, increment of $\mathrm{E}_{2}$ after $\mathrm{P}$ & $(5.2,0.0)$ & $15.8 \pm 9.1$ & $10.0 \pm 5.4$ \\
sponge removal $(\mathrm{pg} / \mathrm{ml})$ & & & \\
\hline
\end{tabular}

Data are expressed as mean \pm SEM. The times $(h)$ are hours from $P$ sponge removal. c, d) Values with different superscripts are significantly different $(\mathrm{P}<0.05)$.

administration of pFSH alone on Day - 2 greatly increased $\mathrm{E}_{2}$ concentrations just after the injection as same as in the F1 group, and then $E_{2}$ levels decreased, followed by a rise after $\mathrm{P}$ sponge removal as shown in Fig. 4 . In the F-2/P-2 and F-1/ $\mathrm{P}-1$ groups, $\mathrm{E}_{2}$ did not increase immediately after the injection of pFSH (Fig. 4, top and bottom panels, and Table 2).

The increment of $E_{2}$ after $P$ sponge removal tended to be larger in the groups that received the eCG treatment on Day - 1 (F-2/P-1 and F-1/P-1) than on Day - 2 (F-2/P-2, Table 2). The main $\mathrm{E}_{2}$ peaks of F-2/P-1 tended to be the highest of all three treatments (Table 2). After the main peak, the $\mathrm{E}_{2}$ levels decreased and became low in all groups.

The $\mathrm{P}_{4}$ levels were less than $1 \mathrm{ng} / \mathrm{ml}$ during period from removal of the $P$ sponge to $42 \mathrm{~h}$ in all the groups, and increased up to $2 \mathrm{ng} / \mathrm{ml}$ on Day 2 to Day 5 (data not shown).

Although we administrated GnRH at the detection of estrus in Trial 2, there was an inconsistency between timing of the main $\mathrm{E}_{2}$ peak and the $\mathrm{LH}$ 

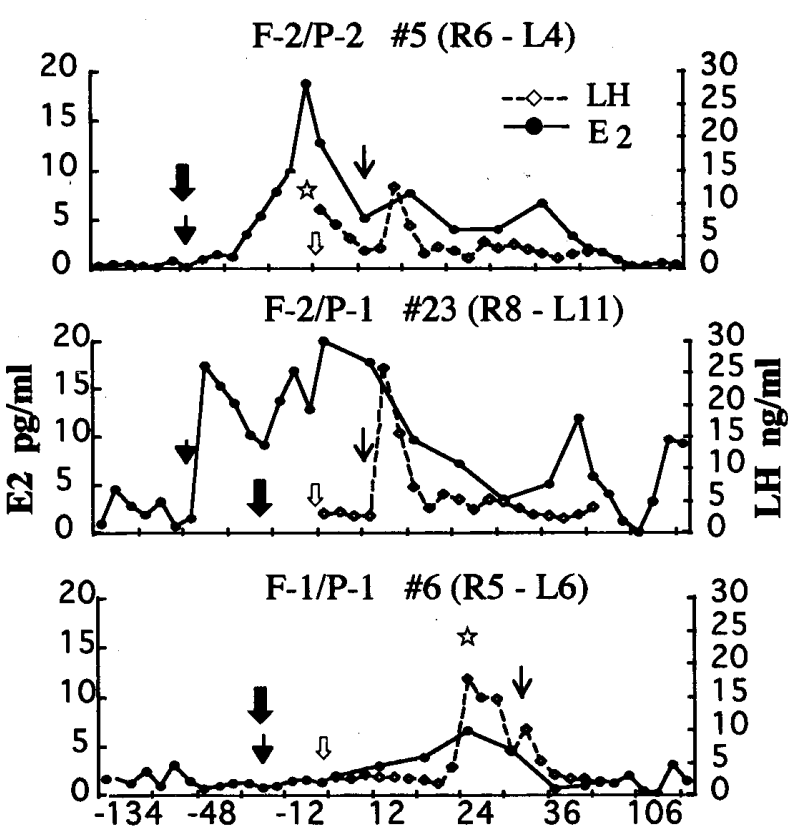

Hours from $P$ sponge removal

$\downarrow \mathrm{pFSH}$ injection $\Omega$ Sponge removal $\downarrow$ GnRH injection

$\downarrow \mathrm{eCG}$ injection \& Endogenous LH surge

Fig. 4. The effects of timing to inject a single dose of $\mathrm{pFSH}$ and eCG on the $\mathrm{E}_{2}$ and $\mathrm{LH}$ concentrations in plasma. Ewes received a single injection of $20 \mathrm{mg}$ pFSH and 500 IU eCG with following schedule. Top, both hormones were given on Day - 2 (F-2/ P-2). Middle, pFSH were injected on Day -2 and eCG on Day - 1 (F-2/P-1). Bottom, both hormones were given on Day - 1 (F-1/P-1). \#: The number of individual ewes; $R$ and L: number of ovulations from the right and the left ovaries, respectively.

peak. Two out of the four ewes in F-2/P-2 and two out of the four ewes in F-1/P-1 had a spontaneous LH surge before the GnRH injection, and one out of the four ewes in F-2/P-1 and one out of the four ewes in F-1/P-1 had a LH surge after the GnRH injection.

\section{Discussion}

The plasma $\mathrm{E}_{2}$ profiles induced by a high dose of $\mathrm{pFSH}$ in combination with a low dose of eCG were almost the same as those of multiple injections with a high dose of pFSH. The present findings are comparable with those of Yamada et al. [12]. If the $\mathrm{E}_{2}$ concentrations represent the number of maturing follicles [20], we can expect this simple superovulation method to result in ovulation and embryo recovery that are equal to those obtained with commonly used method with the multiple administration of pFSH combined with eCG.

Twenty $\mathrm{mg} \mathrm{pFSH}$ is divided into multiple injections $(5,5,3,3,2,2 \mathrm{mg})$ over 2 or 3 days in general superovulation. It must be injected repeatedly and at short intervals because of its short half-life [1]. A single injection of $500 \mathrm{IU}$ of eCG is generally used for inducing multiple ovulations ( $\leq 3$ ovulations) for ewes [21], and the effect continues longer than $\mathrm{pFSH}$ owing to eCG's long half-life [1]. Considering the high concentrations of $\mathrm{E}_{2}$ obtained by the single injection of pFSH combined with eCG (Fig. 1, second panel), there appears to be a synergistic effect of a low dose of eCG and a high dose of $\mathrm{pFSH}$ on $\mathrm{E}_{2}$ production in this simple superovulation method. FSH appeared to play a main role in the recruitment of follicles in the group of potentially ovulatory follicles by increasing aromatase activity [22]. ECG may not only increase the number of follicles due to its FSH-like activity, but also prevent the process of atresia [23] and can contribute to the production of more maturing follicles and to a greater production of $E_{2}$ by increasing production of androgen in the theca cells by its rather strong LH- like activity [24]. ECG can also help to prolong the stimulation to follicles by its long half-life.

Biphasic $E_{2}$ secretion was observed when pFSH was given on Day -2 and eCG was given on Day - 1 (Fig. 4, middle panel), but not when both hormones were given on the same day (Day -2 or Day -1) (Fig. 4, top and bottom panels). Injection of a high dose of $\mathrm{pFSH}$ alone seemed to induce a rapid increase in $E_{2}$, as shown in the example in Fig. 1 (top panel). The simultaneous injections of a low dose of eCG with a high dose of pFSH might have prevented the subsequent elevation of $\mathrm{E}_{2}$. It is not known why this $E_{2}$ reduction occurred by the simultaneous injections, but not by the separated injections of $\mathrm{pFSH}$ and eCG. A combined treatment with $20 \mathrm{mg}$ pFSH and $500 \mathrm{IU}$ eCG might be an overdose for the Suffolk ewe which is a nonprolific breed. The administration of a high dose of gonadotropin accentuates the tendency of luteinization (production of progesterone and oxytocin) by theca interna and granulosa cells, and also inhibits the $\mathrm{E}_{2}$ production by granulosa cells [25]. Premature luteinization of follicles and premature activation of oocytes may occur not only with eCG but also with FSH when high doses are adminis- 
tered [5]. We observed new corpora lutea just after ovulation on the ovary on Day - 1 by laparotomy, which showed the premature ovulation of follicles after the single injection of $\mathrm{pFSH}$ combined with eCG. More detailed investigations on the doses of pFSH and eCG and their effects in different breeds will be required in future studies.

The highly elevated $\mathrm{E}_{2}$ levels that occurred before $\mathrm{P}$ sponge removal as a result of the injections of pFSH on Day - 2 and eCG on Day - 1 might have a deleterious effect on oocyte development and fertilizability due to the exposure to high intrafollicular levels of $E_{2}$ for a prolonged period [5]. However, considering the continuous $\mathrm{E}_{2}$ elevation after the injections of pFSH on Day -2 and eCG on Day -1 , new follicles recruitment, growth and development might have occurred without interruption from Day -2 to the main $E_{2}$ peak.

For hormonal analysis, we used the data from 22 ewes having normal corpora lutea. We also obtained the hormonal profiles from 7 ewes without normal corpora lutea but with many small corpora albicantia (data not shown). Their $\mathrm{P}_{4}$ profiles showed that corpora lutea might have grown normally before laparotomy, but the $\mathrm{P}_{4}$ concentrations were low during on Day 4-7. The ewes without normal corpora luteal had normal $\mathrm{E}_{2}, \mathrm{LH}$ and FSH profiles during superovulation, except for one ewe which received a single injection of $\mathrm{pFSH}$ only. It can be assumed from this fact that these 6 ewes with the normal endocrine profiles of superovulation might have responded normally by the present superovulation treatment, but were suffered from premature regression of corpora lutea when the $\mathrm{P}_{4}$ levels decreased on Day 4-7. The premature regression of corpora lutea is thought to occur by the involvement of the uterus [26] and is suspected to occur by the secretion of prostag- landin F-2 $\alpha$ from the uterus due to the E2 elevation after the LH surge [27]. An $\mathrm{E}_{2}$ elevation might have occurred after observation period in these ewes.

In conclusion, the simple superovulation method, i.e. the administration of a single injection of a high dose $(20 \mathrm{mg}$ ) of pFSH combined with a low dose (500 IU) of eCG, showed comparable endocrine profiles to those obtained by multiple injections of a high dose of $\mathrm{pFSH}$, and in combination with a low dose of eCG. The injection of a low dose of eCG may prolong the stimulatory effect of gonadotropin and maintained the $E_{2}$ concentrations for an extended period. In particular, the injections of pFSH on Day - 2 and eCG on Day -1 caused prolonged $E_{2}$ secretion from Day -2 . In addition to the endocrine profiles reported here, further studies will be needed to fully evaluate this method of superovulation. These will include investigations of the ovulatory responses and the embryo quality recovered from ewes.

\section{Acknowledgements}

The authors thank Mr. K. Sebata, Miss M. Minato, Laboratory of Animal Genetics and Reproduction of Obihiro University for their help, Dr. K. Okuda, Okayama University, for progesterone antiserum, Dr. A. F. Pallow, HARBOR-UCLA Medical Center, USDA, USA, and Dr. S Rait, NIDDK as well as NHPP, University of Maryland School of Medicine, USA, for the ovine FSH radioimmunoassay kit, the Shibecha-cho breeding farm for providing ewes, and Intervet International, Boxmeer, Netherlands, for supplying FGA sponges ("Chrono-gest") used in this study.

\section{References}

1. Boland MP, Roche JF. Embryo production in vivo: problems and prospects. In: Lauria A, Gandolf F (eds.), Embryonic Development and Manipulation in Animal Production. Trends in research and application. Portland press, London, 1992; 195-206.

2. Torres S, Cognie Y, Colas G. Transfer of superovulated sheep embryos obtained with different FSH-P. Theriogenology 1987; 27: 407-419.

3. Elsden RP, Nelson LD, Seidel GE. Superovulating cows with follicle stimulating hormone and preg- nant mare's serum gonadotrophin. Theriogenology 1978; 9: 17-26.

4. Jabbour HN, Evans G. Ovarian and endocrine responses of Merino ewes to treatment with PMSG and/or FSH-P. Anim Reprod Sci 1991; 26: 93-106.

5. Moor RM, Osborn JC, Crosby IM. Gonadotrophin-induced abnormalities in sheep oocytes after superovulation. J Reprod Fertil 1985; 74: 167-172.

6. Mikel Jensen A, Greve T, Madej A, Edqvist L-E. Endocrine profiles and embryo quality in the 
PMSG-PGF $2 \alpha$ treated cow. Theriogenology 1982; 18: 33-44.

7. Shelton JN, Moore NW. The response of the ewe to pregnant mare serum and to horse anterior pituitary extract. J Reprod Fertil 1967; 14: 175-177.

8. Thompson JGE, Simpson AC, James RW, Tervit HR. The application of progesterone-containing

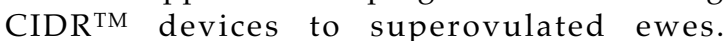
Theriogenology 1990; 33: 1297-1304.

9. Ryan JP, Hunton JR, Maxwell WMC. Increased production of sheep embryos following superovulation of Merino ewes with a combination of pregnant mare serum gonadotrophin and follicle stimulating hormone. Reprod Fertil Dev 1991; 3: 551-560.

10. Evans G, Maxwell WMC, Wilson HR. Superovulation and embryo recovery in Merino ewes. Theriogenology 1994; 41: 192.

11. Batt PA, Killeen ID, Cameron AWN. Use of single or multiple injection of FSH in embryo collection programs in goat. Reprod Fertil Dev 1993; 5: 49-56.

12. Yamada A, Kawana M, Tamura Y, Miyamoto A, Fukui Y. Effect of single or multiple injection of follicle stimulating hormone combined with pregnant mare serum gonadotropin on superovulatory response, and normal and freezable embryos in ewes. J Reprod Dev 1996; 42: 81-87.

13. Yamada A, Takahashi M, Yamamura M, Fukui Y. A simple superovulation and in vivo fertilization of artificially inseminated ewes during the nonbreeding season. Jpn J Sheep Sci 1996; 33: 35-42.

14. Maxwell WMC, Butter LG, Wilson HR. Intrauterine insemination of ewes with frozen semen. $J$ Agric Sci (Camb) 1984; 102: 233-235.

15. Salamon S, Visser D. Effect of composition of Trisbased diluents and thawing solution on survival of ram spermatozoa frozen by the pellet method. Aust J Biol Sci 1972; 25: 605-618.

16. Fukui Y. Effect of diluents, thawing temperatures and materials of thawing containers on survival of ram spermatozoa frozen by the pellet method. Jpn J Anim Reprod 1979; 25: 160-169.

17. Wijayagunawardane MPB, Miyamoto A, Cerbito WA, Acosta M, Takagi M, Sato K. Local distributions of oviductal estradiol, progesterone, prostaglandins, oxytocin and endothelin-1 in cyclic cow. Theriogenology (In press).

18. Miyamoto A, Okuda K, Schewigert FJ, Schams D. Effects of basic fibroblast growth factor, transforming growth factor- $\beta$ and nerve growth factor on the secretory function of the bovine corpus luteum in vitro. J Endocrinol 1992; 135: 103-114.

19. Mutayoba BM, Meyer HHD, Schams D, Schallenberger E. Development of a sensitive immunoassay for LH determination in bovine plasma using he straptavidin-biotin technique. Acta Endocrinl (Copenh) 1990; 122: 227-232.

20. Kishi H, Taya K, Watanabe G, Sasamoto S. Follicular dynamics and secretion of inhibin and oestradiol-17 $\beta$ during oestrus cycle of the hamster. J Endocrinol 1995; 146: 169-176.

21. Samartzi F, Belibasaki S, Vainas E, Boscos C. Plasma progesterone concentration in relation to ovulation rates and embryo yield in Chios ewes superovulated with PMSG. Anim Prod Sci 1995; 39: 11-21.

22. Driancourt MA, Paris A, Dbrauwer L. Aromatase activity of ovine follicular walls: technical validation and physiological control. Reprod Fertil Dev 1996; 8: 875-884.

23. Monniaux D, Mariana JC, Gibson WR. Action of PMSG on follicular populations in the heifer. J Reprod Fertil 1984; 70: 243-253.

24. Fortune JE. Ovarian follicular growth and development in mammals. Biol Reprod 1994; 50: 225-232.

25. Berndtson AK, Vincent SE, Fortune JE. Effect of gonadotrophin concentration on hormone production by theca interna and granulosa cells from bovine preovulatory follicles. J Reprod Fertil 1995; 49 (Suppl): 527-531.

26. Southee JA, Hunter MG, Law AS, Haresign W. Effect of hysterectomy on the short life-cycle corpus luteum produced after GnRH-induced ovulation in the anoestrous ewe. J Reprod Fertil 1988; 84: 149-155.

27. Battye KM, Fairclough RJ, Cameron AWN, Trounson AO. Evidence for prostaglandin involvement in early luteal regression of the superovulated nanny goat (Capra hircus). J Reprod Fertil 1988; 84: 425-430. 